\title{
Platelets of mice heterozygous for neurobeachin, a candidate gene for autism spectrum disorder, display protein changes related to aberrant protein kinase $A$ activity
}

Kim Nuytens ${ }^{1,2+}$, Krizia Tuand ${ }^{1,2+}$, Michela Di Michele ${ }^{3}$, Kurt Boonen ${ }^{1}$, Etienne Waelkens ${ }^{4}$, Kathleen Freson ${ }^{2,3}$ and John WM Creemers ${ }^{1,2^{*}}$

\begin{abstract}
Background: Neurobeachin (NBEA) has been identified as a candidate gene for autism spectrum disorders (ASD) in several unrelated patients with alterations in the NBEA gene. The exact function of NBEA, a multidomain scaffolding protein, is currently unknown. It contains an A-kinase anchoring protein (AKAP) domain which binds the regulatory subunit of protein kinase A (PKA) thereby confining its activity to specific subcellular regions. NBEA has been implicated in post-Golgi membrane trafficking and in regulated secretion. The mechanism of regulated secretion is largely conserved between neurons and platelets, and the morphology of platelet dense granules was found to be abnormal in several ASD patients, including one with NBEA haploinsufficiency. Platelet dense granules are secreted upon vascular injury when platelets are exposed to for instance collagen. Dense granules contain serotonin, ATP and ADP, which are necessary for platelet plug formation and vascular contraction.

Methods: To further investigate possible roles for NBEA in secretion or dense granule morphology, platelets from $\mathrm{Nbea}^{+/-}$mice were analyzed morphometrically, functionally and biochemically. A differential proteomics and peptidomics screen was performed between $\mathrm{Nbea}^{+/-}$and $\mathrm{Nbea}^{+/+}$mice, in which altered Talin-1 cleavage was further investigated and validated in brain samples. Finally, the phosphorylation pattern of PKA substrates was analyzed.

Results: Platelet dense granules of $\mathrm{Nbea}^{+/-}$mice had a reduced surface area and abnormal dense-core halo, but normal serotonin-content. Nbea haploinsufficiency did not affect platelet aggregation and ATP secretion after collagen stimulation, although the platelet shape change was more pronounced. Furthermore, peptidomics revealed that $\mathrm{Nbea}^{+/-}$platelets contain significantly reduced levels of several actin-interacting peptides. Decreased levels were detected of the actin-binding head and rod domain of Talin-1, which are cleavage products of Calpain-2. This is most likely due to increased PKA-mediated phosphorylation of Calpain-2, which renders the enzyme less active. Analysis of other PKA substrates revealed both increased and reduced phosphorylation.

Conclusion: Our results show the pleiotropic effects of alterations in PKA activity due to Nbea haploinsufficiency, highlighting the important function of the AKAP domain in Nbea in regulating and confining PKA activity. Furthermore,
\end{abstract} these results suggest a role for Nbea in remodeling the actin cytoskeleton of platelets.

Keywords: Autism spectrum disorder, AKAP, Calpain, Candidate gene, Neurobeachin, Platelets, Serotonin, Talin-1

\footnotetext{
*Correspondence: John.Creemers@med.kuleuven.be

${ }^{\dagger}$ Equal contributors

'Department of Human Genetics, Laboratory for Biochemical

Neuroendocrinology, KU Leuven, 3000 Leuven, Belgium

'2Leuven Autism Research Consortium (LAuRes), KU Leuven, 3000 Leuven,

Belgium

Full list of author information is available at the end of the article
} 


\section{Background}

The genetic architecture of autism spectrum disorders (ASDs) is highly heterogeneous and to date more than 100 genes have been reported to be deleted, duplicated, mutated or disrupted by a translocation breakpoint in ASD patients [1,2]. One of these candidate genes, Neurobeachin (NBEA) [MIM: 604889] was identified in a patient with a de novo balanced chromosomal translocation $\mathrm{t}(5 ; 13)$ (q12.1; q13.2) with one breakpoint in intron 2 of $N B E A$ resulting in a NBEA haploinsufficient status [3]. Additionally, four unrelated ASD patients with a monoallelic deletion of $N B E A$ were reported [4-7], and three novel CNVs were detected within the $N B E A$ gene in three unrelated individuals diagnosed with ASD [8-10]. Moreover, a single nucleotide polymorphism (SNP) in intron 38 of NBEA has been associated with ASD [11]. The NBEA gene contains a lowfrequency common fragile site (FRA13) linked to ASD and is located in a $19 \mathrm{cM}$ region identified as a candidate region for ASD by a linkage study (MMLS/het score of 2.3 between markers D13S217 at $17.21 \mathrm{cM}$ and D13S1229 at $21.51 \mathrm{cM})$ [12-14].

NBEA, a brain-enriched multidomain scaffolding protein, is located at the tubulovesicular endomembranes near the trans-Golgi network [15,16]. The N-terminal region contains a Concanavalin A-like lectin domain flanked by armadillo repeats suggested to play a role in intracellular trafficking $[17,18]$. Distal from these regions, an A-kinase anchoring protein (AKAP) domain is present, recruiting cAMP-dependent protein kinase A (PKA) by high-affinity binding to its regulatory RII $\alpha$ subunit [16]. The C-terminal part of NBEA possesses a pleckstrin homology - beige and Chediak-Higashi (BEACH) - WD40 domain module which is thought to be implicated in vesicle trafficking $[16,19]$. NBEA and eight other human proteins contain the highly conserved $\mathrm{BEACH}$ domain, and thus belong to the family of BEACH proteins [20].

Although the exact function of NBEA is currently unknown, a complete loss of Nbea in mice leads to a perinatal lethal phenotype due to a complete block of evoked neuromuscular transmission [21]. By studying neuronal cultures derived from E18 $\mathrm{Nbea}^{-1-}$ mice, a role emerges for Nbea in trafficking important cargo to pre- and postsynaptic compartments, as these cultures have shown abnormal large clusters of actin in the soma, dendritic shafts and axons, and a reduced level of neurotransmitter receptors has been detected at the surface of the postsynaptic membrane $[22,23]$. Moreover, knockdown of Nbea in a neuroendocrine cell line ( $\beta$ TC3 cells) leads to enhanced secretion of dense-core secretory granules, the neuroendocrine counterpart of large dense-core vesicles (LDCVs) in neurons, making Nbea a negative regulator of the regulated secretion [24].

Blood platelets are the first players to be activated upon vascular injury. They are essential for initiating platelet plug formation and do so by secreting the content of their secretory granules. Similar to neurons, platelets contain two types of secretory granules, namely the alpha and dense granules, corresponding to the small synaptic vesicles (SVs) and LDCVs in neurons, respectively [25]. Blood platelet alpha granules have a heterogeneous cargo of polypeptides ranging from adhesion molecules to growth factors, whereas dense granules contain the small molecules ATP, ADP and serotonin, necessary for vasoconstriction. Due to the similar regulation of granule formation and transport, platelets were put forward as a model system to study the biology of granule formation, trafficking and secretion in neurons $[26,27]$. Preliminary in vivo analysis unveiled an abnormal morphology of the dense granules in platelets of our reported patient with a chromosomal translocation in NBEA [24]. Moreover, similar platelet granule abnormalities were observed in ASD patients with chromosomal rearrangements in Amisyn or SCAMP5, and in an ASD patient with a deletion including SHANK3 [24]. Interestingly, mutations in LYST and NBEA-like 2 (NBEAL2), two other BEACH proteins, are described in patients with Chediak-Higashi and Gray platelet syndrome and result in abnormal to absent platelet dense and alpha granules, respectively [28,29].

As platelets can easily be obtained from patients, further insights into platelet abnormalities might lead to the identification of biomarkers associated with ASD. We have characterized platelets from mice heterozygous for Nbea to substantiate the causality of NBEA haploinsufficiency for the abnormal platelet phenotype. The ultrastructure of the dense granules of murine platelets was analyzed and platelet function was investigated. Moreover, serotonin levels were determined in both serum and platelets, as hyperserotonemia is the only biochemical anomaly reported in approximately $30 \%$ of ASD patients. Serotonin is a hormone and monoamine neurotransmitter that can induce vasoconstriction and is implicated in neuron outgrowth, maturation, function and plasticity. It is synthesized in serotonergic neurons of the central nervous system and in the intestine, and more than $99 \%$ of whole blood serotonin is stored in blood platelets [30]. To assess whether Nbea haploinsufficiency affects the protein and peptide content of platelets, a full proteomic and peptidomic analysis was performed and results were further validated in platelets and in total brain.

\section{Methods}

All experiments were approved by the ethical research committee of KU Leuven in accordance with the declaration of Helsinki (project number P182/2011).

\section{Animals}

The GH240B transgenic line described in Su et al. [21] was backcrossed for at least 10 generations with C57BL/ 
6JRj mice (Janvier). Peripheral blood samples were obtained from adult (12-week-old) female mice.

Brains were dissected from 12-week-old mice and immediately put at $-80^{\circ} \mathrm{C}$. Tissue was homogenized in sucrose buffer (3.18 mM sucrose; $4 \mathrm{mM}$ Tris- $\mathrm{HCl} \mathrm{pH}$ 7.4) containing a protease and phosphatase inhibitor cocktail and a complete protease inhibitor cocktail (both from Roche Applied Science, Penzberg, Germany).

\section{Platelet function analysis and platelet counts}

Murine blood was anticoagulated with 3.2\% trisodium citrate (9:1) and mean platelet volume (MPV) and platelet count were determined on an automated cell counter (Cell-Dyn 1300 Abbott laboratories, Abbott Park, IL, USA). Platelet-rich plasma (PRP) was obtained after centrifugation at 3,000 rpm for $30 \mathrm{sec}$ followed by $800 \mathrm{rpm}$ for 5 minutes. The platelet count was adjusted to 250,000 platelets $/ \mu \mathrm{l}$ with autologous plasma. Platelet aggregation and secretion were performed as described after stimulation with Horm collagen $(5 \mu \mathrm{g} / \mathrm{ml})[31,32]$. Platelet secretion was determined by measuring the release of ATP using luciferin/ luciferase reagent (Kordia, Leiden, The Netherlands). Electron microscopy analysis of murine platelets was performed as previously reported [33]. Additional ultra-thin sections of 50 to $70 \mathrm{~nm}$ were cut, stained with uranyl acetate and lead citrate, and examined at $80 \mathrm{kV}$ using a JEM1400 transmission electron microscope (JEOL, Tokyo, Japan). Micrographs were acquired on an SIS Quemesa camera (Olympus, Münster, Germany). The number of dense granules per platelet and dense granule dimension and morphology were further assessed with the ImageJ imaging system (National Institutes of Health, Bethesda, MD, USA) ( $\mathrm{n}=200$ platelets/genotype). Dense granules were classified as different types: type 1, solid core occupying more than $50 \%$ of the granule; type 2 , solid core occupying less than $50 \%$ of the granule; type 3 , fragmented core; or type 4 , empty granule/no visible core $[34,35]$.

\section{Determination of platelet size and distribution by flow cytometry}

Integrin $\alpha \operatorname{IIb} \beta 3$ expression was measured in whole blood by incubation with fluorescein isothiocyanate (FITC)-conjugated anti-CD41/61 monoclonal antibody (BD Biosciences, Bergen County, NJ, USA) for 15 minutes. Forward and side scatter and percentage platelets to total cell number were analyzed using FACSDiva version 6.1.2 software (BD Biosciences) on a FACSCalibur flow cytometer (BD Biosciences).

\section{Platelet isolation for protein analysis}

Peripheral blood samples were obtained from the retroorbital sinus (anticoagulated with ACD pH6.5 (7 mM citric acid; $93 \mathrm{mM}$ sodium citrate; $140 \mathrm{mM}$ dextrose); 9:1). PRP was obtained as described above. Platelets were obtained by PRP centrifugation at 2,300 rpm for 10 minutes and washed twice with ACD pH6.5. For proteomic purposes, PRP of littermates with the same genotype was pooled to yield sufficient protein contents to prepare the platelet pellets.

\section{Determination of serotonin levels in platelets and serum}

Serum was obtained from blood coagulated for 30 minutes at $37^{\circ} \mathrm{C}$ in glass cuvettes followed by centrifugation at 2,300 rpm for 10 minutes. Serotonin content of platelets, isolated as mentioned above, and serum was calculated using the serotonin research ELISA (Labor Diagnostika Nord, Nordhorn, Germany) according to the protocol of the manufacturer ( $\mathrm{n}=8$ mice/genotype).

\section{Two dimensional-differential gel electrophoresis (2D-DiGE)}

Platelet pellets ( $\mathrm{n}=4$ samples/genotype) were lysed in DiGE lysis buffer containing $7 \mathrm{M}$ urea, $2 \mathrm{M}$ thiourea, $4 \%$ CHAPS and $30 \mathrm{mM}$ Tris $\mathrm{pH} 8.5$ and a complete protease inhibitor cocktail (Roche Applied Science, Penzberg, Germany). The samples were purified with the 2D Clean-Up Kit (GE Healthcare, Buckinghamshire, UK) and the concentration was determined using the 2D Quant Kit (GE Healthcare) according to the manufacturer's guidelines. Proteins were labeled with carbocyanine (Cy) dyes as previously described [31]. Briefly, 50 $\mu \mathrm{g}$ of each sample was labeled with $200 \mathrm{pmol}$ of Cy3 or Cy5. To avoid possible bias due to labeling efficiency, two samples of each genotype were labeled with Cy3 and the other two with Cy5. The internal standard consisting of a pool of all samples was labeled with Cy2 allowing a quantitative comparison for a protein of two samples resolved on the same gel (ratio $\mathrm{Cy} 3 / \mathrm{Cy} 2$ and $\mathrm{Cy} 5 / \mathrm{Cy} 2$ ) and a quantitative comparison of multiple gels. Mixtures of Cy3-, Cy5- and Cy2-labeled samples were diluted 1:1 with lysis buffer containing 0.5\% IPG buffer ( $\mathrm{pH} 4$ to 7 ) and 1.3\% dithiothreitol (DTT) and applied by cup loading on rehydrated IPG strips (pH 4 to $7,18 \mathrm{~cm}$ ). The first dimension was carried out in an IPGphor system (GE Healthcare) with the following conditions: $1 \mathrm{~h} 30$ minutes at $150 \mathrm{~V}, 2 \mathrm{~h}$ at $500 \mathrm{~V}, 5 \mathrm{~h}$ at $1,000 \mathrm{~V}, 3 \mathrm{~h}$ at $8,000 \mathrm{~V}$ in gradient and $5 \mathrm{~h}$ at $8,000 \mathrm{~V}$. IPG strips were subsequently incubated in equilibration buffer (6 M urea, 30\% glycerol, $2 \%$ SDS and 50 $\mathrm{mM}$ Tris $\mathrm{pH}$ 8.5) supplemented with $65 \mathrm{mM}$ DTT for 20 minutes and followed by incubation in equilibration buffer supplemented with $200 \mathrm{mM}$ iodoacetamide and $0.02 \%$ bromophenol blue for 20 minutes. The second dimension was performed on $11 \%$ polyacrylamide gels on the Hoefer DALT vertical system (GE Healthcare). Visualization and analysis of the images as well as the identification of differentially expressed proteins were executed as described previously [31]. 


\section{Immunoblot analysis}

Platelet pellets were resolved in lysis buffer (1\% Igepal; 0,015\% DTT; $1 \mathrm{mM}$ ethylene diamine tetraacetic acid (EDTA) in PBS supplemented with a complete protease inhibitor cocktail) (Roche Applied Science). Protein concentration of the platelet and brain lysates was quantified with a bicinchoninic acid (BCA) protein assay (Thermo Scientific, Rockford, IL, USA). Depending on the molecular weight of the protein of interest, $25 \mu \mathrm{g}$ of platelet or brain lysates was loaded on a $10 \%$ Bis-Tris gel (Bio-Rad, Hercules, CA, USA) or 3 to 8\% Tris-Acetate gel (Life technologies, Paisley, UK). Proteins were transferred to Protan Nitrocellulose membrane (Schleicher \& Schuell, Dassel, Germany) and incubated with antibodies against Munc13-4 (Santa Cruz Biotechnology, Santa Cruz, CA, USA; 1/1,000), Rab27b (homemade antibody, 1/1,000), Calmodulin (kindly provided by Professor $\mathrm{H}$ Desmedt, KU Leuven; 1/1,000), Talin-1 (Cell Signaling Technology, Danvers, MA, USA; 1/500), Calpain-2 large subunit (Cell Signaling Technology; 1/1000), Calpain-4 regulatory subunit (Santa Cruz Biotechnology; 1/ 1,000), phospho-(Ser/Thr) PKA substrate antibody (Cell Signaling Technology; 1/1,000), and actin (Sigma-Aldrich, St Louis, MO, USA; 1/5,000), used for normalization. Equal amounts of actin protein expression were verified after incubation with an antiglyceraldehyde-3-phosphate dehydrogenase (GAPDH) antibody (Abcam, Cambridge, UK; 1/15,000). Afterwards, membranes were incubated with horseradish peroxidase (HRP)-conjugated secondary antibody (1/ 2,000; DAKO, Glostrup, Denmark) and proteins were visualized with western blotting ECL detection reagent. Quantification was performed using the Kodak Imager software (Kodak, Rochester, NY, USA).

\section{Immunoprecipitation}

Per sample, $20 \mu \mathrm{l}$ of $50 \%$ bead slurry of protein A agarose beads (GE Healthcare) was used and washed twice with PBS before use. All incubations were performed at $4^{\circ} \mathrm{C}$ on a mechanical rotator. Prior to immunoprecipitation, pre-clearing of the platelet or brain sample was performed as follows. Protein A agarose beads were incubated with rabbit serum (ImmuniBioScience, Mukiltoe, WA, USA) for $1 \mathrm{~h}$ after which $60 \mu \mathrm{g}$ of platelet or brain sample was added for $1 \mathrm{~h}$. The immunoprecipitation was subsequently performed with the pre-cleared supernatant by adding phospho-(Ser/Thr) PKA substrate antibody (Cell signaling technology; 1/100) for overnight incubation, followed by an additional $2 \mathrm{~h}$ incubation with protein A agarose beads. Beads were washed five times with PBS and proteins were harvested by resuspension of the beads in sample buffer (50 mM Tris- $\mathrm{HCl} \mathrm{pH} \mathrm{7;10 \%}$ glycerol; 2\% SDS; bromophenol blue) compatible with immunoblot analysis.

\section{Peptidomics}

Platelets were isolated as described above with modification of the final wash buffer, which was now replaced by PBS. The procedure for processing the platelet pellets $(n=5$ mice/genotype) for mass spectrometry analysis was performed as reported [36]. DeCyder MS 2.0 (GE Healthcare) is a differential analysis software tool that also allows for easy visualization of liquid chromatography mass spectrometry (LC-MS) runs by creating artificial two-dimensional maps with the $m / z$ values and retention times in the first and second dimension, respectively. Time alignment, intensity normalization and statistics were performed using this software. Peptides were identified in additional LC-MS/MS runs of the pooled samples as reported in [36] using LC quadrupole time-of-flight (Q-TOF) MS.

\section{Statistical analysis}

Data are presented as mean \pm standard error of the mean (SEM). Significance of differences was analyzed using (where appropriate) the two-tailed $t$-test, $t$-test for single means, Mann-Whitney $U$-test (MWU) or Pearson Chi-square test using Statistica version 9.0 (StatSoft Inc., Tulsa, OK, USA). All statistical tests were performed with 0.05 as the $\alpha$-level of significance $(" P<0.05$, ${ }^{* * *} P<0.01$ and $\left.{ }^{* * * *} P<0.001\right)$.

\section{Results}

$\mathrm{Nbea}^{+/-}$mice have normal platelet counts and MPV

Heterozygous Nbea mice had a similar platelet count (n $=10 /$ genotype; two-tailed $t$-test, $P=0.20$ (Table 1 ) and MPV (n = 10/genotype; two-tailed $t$-test, $P=0.58$ ) (Table 1) compared to wild-type mice. The normal platelet size, distribution and count was confirmed by means of flow cytometry analysis, as no differences could be detected in forward and side scatter or in percentage CD41/61-positive platelets relative to the total blood cell-number ( $\mathrm{n}=10 /$ genotype; two-tailed $t$-test, $P=$ $0.83, P=0.34$ and $P=0.10$, respectively) (Table 1 ).

\section{Abnormal dense granules in platelets of $\mathrm{Nbea}^{+/-}$mice}

The ultrastructure of the platelets of $\mathrm{Nbea}^{+/-}$mice $(\mathrm{n}=$ 200 platelets/genotype) was assessed to detect previously described alterations in dense granule cores as described for a patient haploinsufficient for NBEA [24] (Figure 1A). The number of dense granules per platelet was similar for $\mathrm{Nbea}^{+/-}$and $\mathrm{Nbea}^{+/+}$mice (MWU, $P=0.94$ ) (Table 1). However, the total surface area within the limiting membrane of the dense granules of platelets of $\mathrm{Nbea}^{+/-}$mice was significantly reduced (MWU, $P<0.001$ ) (Table 1 , Figure 1), due to a reduced surface area of the halo surrounding the dense-core (MWU, $P=0.001$ ) (Table 1 ). Based on the appearance of the dense-core, dense granules were subdivided into 4 different types according to Weiss et al. [35]. No significant difference between genotypes 
Table 1 Morphological and functional characteristics of blood platelets haploinsufficient for Neurobeachin

\begin{tabular}{|c|c|c|c|}
\hline & $\mathrm{Nbea}^{+/+}$ & $\mathrm{Nbea}^{+/-}$ & $P$ \\
\hline Platelet count $\left(10^{3} / \mu \mathrm{l}\right)$ & $943.6 \pm 41.9$ & $864.9 \pm 42.2$ & 0.20 \\
\hline Mean platelet volume (fL) & $6.52 \pm 0.11$ & $6.61 \pm 0.12$ & 0.58 \\
\hline \multicolumn{4}{|l|}{ Flow cytometry } \\
\hline Forward scatter (AU) & $13,683.3 \pm 667.3$ & $13,853.8 \pm 255.9$ & 0.83 \\
\hline Side scatter (AU) & $1,038.5 \pm 21.5$ & $1,012.4 \pm 13.3$ & 0.34 \\
\hline Platelets/cell total (\%) & $9.88 \pm 0.53$ & $8.46 \pm 0.57$ & 0.10 \\
\hline \multicolumn{4}{|l|}{ Dense granules } \\
\hline Number/platelet & $0.445 \pm 0.028$ & $0.441 \pm 0.028$ & 0.94 \\
\hline Surface area $\left(\mathrm{nm}^{2}\right)$ & $18,063.1 \pm 696.2$ & $14,331.3 \pm 649.7$ & $<0.001$ \\
\hline Dense-core area $\left(\mathrm{nm}^{2}\right)$ & $2,375.4 \pm 251.2$ & $1,706.4 \pm 183.0$ & 0.52 \\
\hline Halo area $\left(\mathrm{nm}^{2}\right)$ & $15,687.7 \pm 654.1$ & $12,624.9 \pm 607.4$ & 0.001 \\
\hline \multicolumn{4}{|l|}{ Dense granule classification } \\
\hline Type 1 (\%) & 13.4 & 10.6 & 0.73 \\
\hline Type 2 (\%) & 26.7 & 29.3 & \\
\hline Type 3 (\%) & 1.4 & 1.9 & \\
\hline Type 4 (\%) & 58.5 & 58.2 & \\
\hline \multicolumn{4}{|l|}{ Serotonin content } \\
\hline Serum $(n g / \mu l)$ & $1.99 \pm 0.25$ & $2.21 \pm 0.14$ & 0.45 \\
\hline Platelets ( $\mu \mathrm{g} / 10^{9} \mathrm{PLTs}$ ) & $7.59 \pm 1.62$ & $6.84 \pm 1.61$ & 0.75 \\
\hline \multicolumn{4}{|l|}{ Aggregation (amplitude \%) } \\
\hline Collagen $(5$ g/ml) & $54.4 \pm 5.7$ & $52.8 \pm 3.8$ & 0.82 \\
\hline \multicolumn{4}{|l|}{ ATP secretion $(\mu \mathrm{M})$} \\
\hline Collagen $(5 \mu \mathrm{g} / \mathrm{ml})$ & $1.58 \pm 0.41$ & $1.71 \pm 0.67$ & 0.87 \\
\hline
\end{tabular}

Platelet count and size were investigated in 10 mice/genotype. Dense granule morphology (MWU test) and classification was analyzed in 200 platelets/genotype. Dense granule classification was based on the study by Weiss et al. [35] and the total amount of dense granules counted per genotype was set at $100 \%$ yielding the above-mentioned separate percentage per dense granules type. The distribution of the dense granules into the classification types was compared between $\mathrm{Nbea}^{+/-}$and $\mathrm{Nbea}^{+/+}$mice using the Pearson Chi-square test. Serotonin content was measured in eight mice/genotype. Platelet function was assessed in four mice/genotype. ATP secretion and aggregation were measured for 5 minutes after collagen stimulation. Unless stated otherwise, parameters were compared between genotypes using the two-tailed $t$-test. Data are represented as mean \pm standard error of the mean. AU, arbitrary units; PLT, platelet.

was detected in the presence of the four types of granules in platelets (Pearson Chi-square test, $P=0.73$ ) (Table 1 ).

\section{Normal serotonin levels in heterozygous Nbea mice}

Serotonin secreted from enterochromaffin cells enters the blood stream where it is actively taken up by platelets and stored in dense granules [37]. Platelet and serum serotonin levels were measured, but no significant difference could be detected between $\mathrm{Nbea}^{+/+}$ mice and $\mathrm{Nbea}^{+/-}$mice $(\mathrm{n}=8$ mice/genotype; twotailed $t$-test, $P=0.75$ and $P=0.45$, respectively) (Table 1).

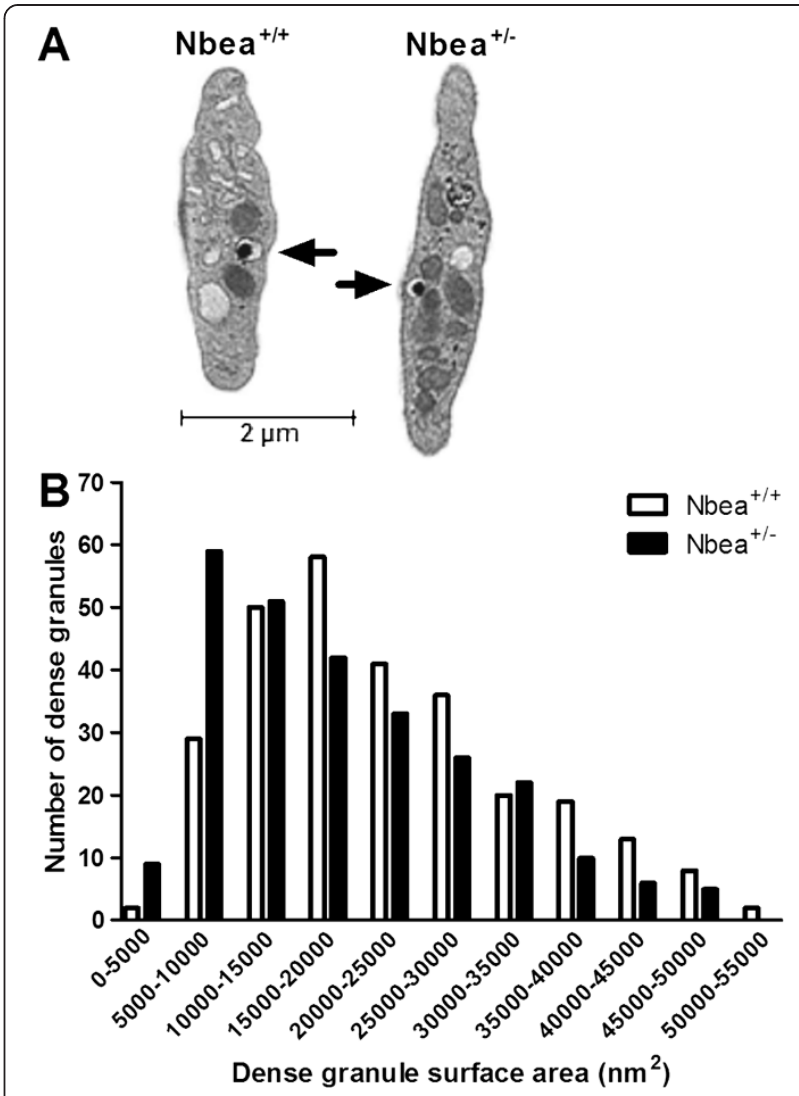

Figure 1 Reduced total surface area of dense granules due to a decrease in surface area of the halo in platelets of $\mathrm{Nbea}^{+/}$ mice. (A) Electron microscopic view of a blood platelet of $\mathrm{Nbea}^{+/+}$and $\mathrm{Nbea}^{+/-}$mice. Dense granules are indicated with black arrows. (B) Distribution of dense granule number according to their surface area. Dense granules of platelets of $\mathrm{Nbea}^{+/-}$mice were significantly smaller than dense granules of platelets of $\mathrm{Nbea}^{+/+}$mice ( $\mathrm{n}=200$ platelets/genotype).

Subtle changes in platelet function in $\mathrm{Nbea}^{+/-}$mice Platelet function was measured by the ATP secretion and aggregation test. In line with measurements of comparable serotonin levels, dense granules from wild-type and heterozygous Nbea mice secrete similar levels of ATP upon collagen stimulation $(n=4$ mice/genotype; two-tailed $t$-test, $P=0.87$ ) (Table 1 ).

Collagen binds to its glycoprotein receptors on the plasma membrane of platelets, resulting in the activation of phospholipase $\gamma 2$ leading to an increase of intracellular $\mathrm{Ca}^{2+}$. The subsequent critical event is the reorganization of the actin cytoskeleton underlying filopodia and lamellopodia formation. This process is the essence of the platelet shape change which precedes platelet aggregation [38]. Although platelet aggregation after collagen stimulation was normal for $\mathrm{Nbea}^{+-}$mice $(\mathrm{n}=4$ mice/genotype; twotailed $t$-test, $P=0.82$ ) (Table 1 ), they consistently presented with a more pronounced shape change after collagen activation (Figure 2). 


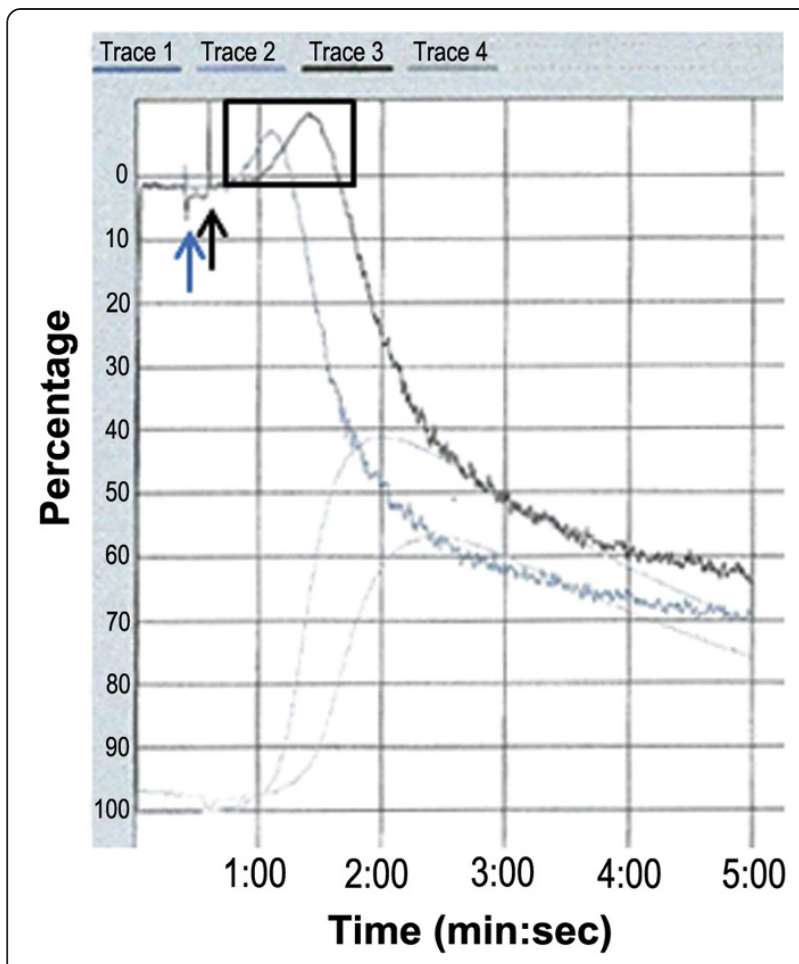

Figure 2 More pronounced shape change of platelets of $\mathrm{Nbea}^{+/-}$ mice upon collagen stimulation. Collagen was added to wild-type and heterozygous platelet-rich plasma samples, respectively, at time points indicated by the blue and black arrows. Upon collagen stimulation, ATP secretion and aggregation were measured in the following 5 minutes. Trace 1 and 3 visualize the aggregation of platelets from $\mathrm{Nbea}^{+/+}$and $\mathrm{Nbea}^{+/-}$mice, respectively. The shape change preceding the aggregation is indicated with a black rectangle. All replication experiments show a similar, more pronounced shape change for $\mathrm{Nbea}^{+\prime}$ mice. Traces 2 and 4 are the visualization of the ATP secretion of platelets of $\mathrm{Nbea}^{+/+}$and $\mathrm{Nbea}^{+/-}$mice, respectively ( $\mathrm{n}=4$ mice/genotype). Quantification of total ATP secretion was done after corrections for background values (ATP secretion in platelet-poor plasma). Though it seems that there were differences between the ATP secretion curves for $\mathrm{Nbea}^{+/+}$and $\mathrm{Nbea}^{+/-}$mice in this experiment, quantification of ATP secretion values after correction for backgrounds in triplicate experiments, as shown in Table 1, showed no significant differences between genotypes.

\section{Proteomic profile of platelets heterozygous for $\mathrm{Nbea}$}

To identify proteins differentially expressed in platelets of $\mathrm{Nbea}^{+/-}$mice, a 2D-DiGE experiment was performed ( $\mathrm{n}=$ 4 samples/genotype). A representative gel of the protein profile of platelets of $\mathrm{Nbea}^{+/+}$and $\mathrm{Nbea}^{+/-}$mice is shown in Additional file 1. Each gel contained at least 1,432 genuine protein spots, based on a manual verification of the three-dimensional profile characteristics. Only proteins present in at least $50 \%$ of the gel images were included for statistical analysis. A difference in expression was found for a total of 21 proteins, with 10 proteins having a reduced expression level and 11 proteins with an increased expression level in platelets of $\mathrm{Nbea}^{+/-}$mice compared to platelets of $\mathrm{Nbea}^{+/+}$mice (Additional file 1). Post-translational modifications probably explain the different positions of the identified proteins on the gel. However, no significant differences in expression level were observed, as the change in these 21 proteins was never greater than 1.3fold, the reliable threshold for differential expression in 2D-DiGE experiments.

In addition, western blot was performed for several proteins related to dense granule biogenesis and secretion. The actin protein expression in platelets of $\mathrm{Nbea}^{+/-}$mice was comparable with the actin levels in $\mathrm{Nbea}^{+/+}$mice, although contradictory findings are reported with regard to altered total actin levels in $\mathrm{Nbea}^{-/-}$mice $[22,23,39,40]$. Additional western blot analysis confirmed no differences in actin protein expression levels, when normalized to the GAPDH content, between $\mathrm{Nbea}^{+/+}$and $\mathrm{Nbea}^{+/-}$mice $(\mathrm{n}=$ 4 samples/genotype; two-tailed $t$-test, $\mathrm{P}=0.56$ ) (Figure $3 \mathrm{~A}$ ). Therefore, total actin level can be used as an internal control for western blot analysis. The expression of Munc13-4, Rab27b and Calmodulin after actin normalization did not significantly differ between $\mathrm{Nbea}^{+/+}$and $\mathrm{Nbea}^{+/-}$mice $(\mathrm{n}=$ 4 samples/genotype; two-tailed $t$-test; Munc13-4, $P=0.77$; Rab27b, $P=0.51$; Calmodulin, $P=0.81$ ) (Figure $3 \mathrm{~B}$ ).

\section{Differential peptidomics of platelets of $\mathrm{Nbea}^{+/-}$mice}

Platelets contain a wide variety of peptides as well as proteins [41]. The peptide content of platelets of wild-type and heterozygous Nbea mice were compared by LC Q-TOF MS. Only peptides that were sufficiently abundant, wellaligned in time and present in at least three out of five samples were considered for statistical analysis. This resulted in approximately twenty differential peptides of which six could be identified ( $n=5$ mice/genotype) (Table 2). Quantification revealed significantly lower levels of six peptides, namely Thymosin $\beta 4$ (full length and fragments containing amino acids (AA) 1 to 18 and 19 to 43; two-tailed $t$-test, $P=0.048$ ), full length Thymosin $\beta 10$ (two-tailed $t$-test, $P=$ 0.020), Talin-1 (peptide containing AA 449 to 465; twotailed $t$-test, $P=0.032$ ) and the $\mathrm{C}$-terminal part of Transgelin-2 (peptide containing AA 178 to 199; two-tailed $t$-test, $P=0.028)$. Interestingly, all these proteins are described as modulators of the actin cytoskeleton.

\section{Altered cleavage of Talin-1 and altered phosphorylation of Calpain-2 in $\mathrm{Nbea}^{+/-}$mice}

The peptide identified as Talin-1 (AA 449-465) is most likely a degradation product as Talin-1 is a high-molecularweight protein of $270 \mathrm{kDa}$. Talin-1 consists of two domains, a head domain $(49 \mathrm{kDa})$ and a rod domain $(220 \mathrm{kDa})$ joined by a linker region containing a Calpain-2 (m-Calpain) cleavage site $[43,44]$. Western blot was performed for Talin1 to assess the expression level and cleavage in platelets of $\mathrm{Nbea}^{+/-}$mice ( $\mathrm{n}=4 \mathrm{samples} /$ genotype). The expression level of full-length Talin-1 was slightly increased in platelets of $\mathrm{Nbea}^{+/-}$mice but the difference was not significant (two- 


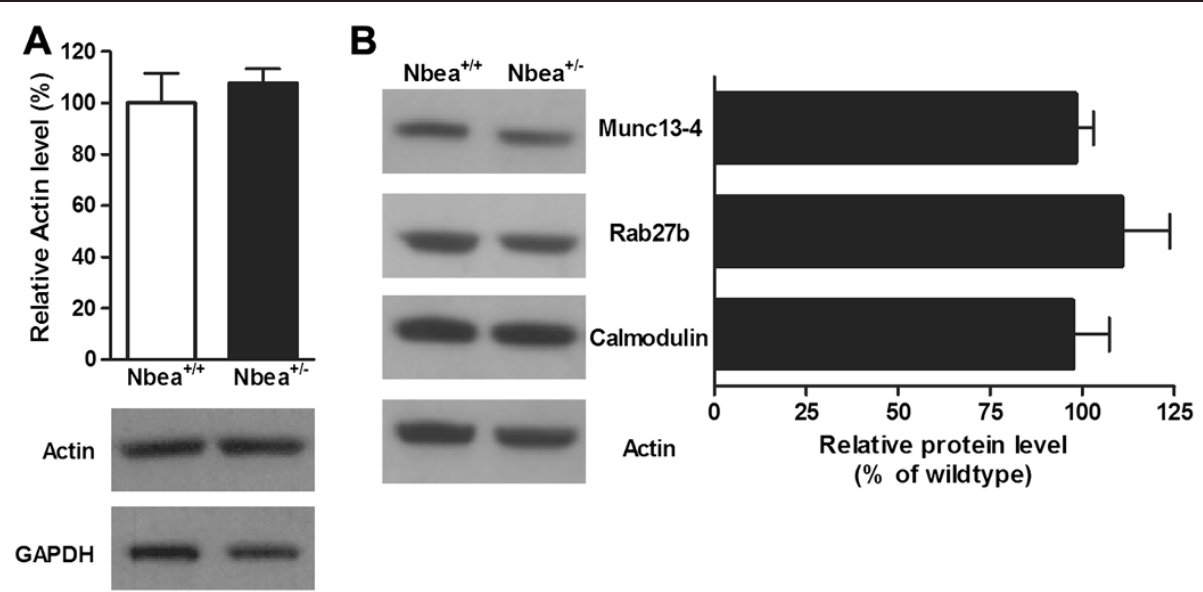

Figure 3 Normal expression of actin and the proteins involved in dense granule formation and secretion in platelets of $\mathrm{Nbea}^{+/-}$mice. $^{\mathrm{a}}$ (A) Western blot analysis detected no changes in the total actin levels in platelets of $\mathrm{Nbea}^{+/-}$mice compared to Nbea ${ }^{+/+}$mice. Actin expression was normalized to the glyceraldehyde-3-phosphate dehydrogenase (GAPDH) content and the expression in platelets of wild-type mice was set at 100\% ( $n=4 /$ genotype). (B) The total amount of Munc13-4, Rab27b and Calmodulin was unaltered in platelets of Nbea ${ }^{+-}$mice. Protein levels were normalized to actin and the expression level in platelets of $\mathrm{Nbea}^{+/+}$mice was set at $100 \%$ ( $n=4$ samples/genotype).

tailed $t$-test, $P=0.35$ ) (Figure 4A). However, the presence of cleavage products of Talin-1 was markedly reduced in platelets of $\mathrm{Nbea}^{+/-}$mice compared to $\mathrm{Nbea}^{+/+}$mice, as the expression of both the rod and head domain was significantly decreased (two-tailed $t$-test, $P=0.018$ and $P=0.002$, respectively) (Figure 4A). To extrapolate these findings to brain, Talin-1 cleavage was studied in total brain lysates ( $\mathrm{n}=5$ samples/genotype). As with platelet samples, the presence of the head domain was significantly reduced in the brain tissue of $\mathrm{Nbea}^{+/-}$mice compared to $\mathrm{Nbea}^{+++}$ mice ( $t$-test for single means, $P=0.04$ ) (Figure $4 \mathrm{~B}$ ) and full-length Talin-1 showed no significant difference in expression ( $t$-test for single means, $P=0.55$ ). There were several unsuccessful attempts to quantify the presence of the rod domain of Talin-1, due to a low signal-to-noise ratio for this domain. However, the reduced ratio of the head domain versus full-length Talin-1 indicates that in the brain tissue of $\mathrm{Nbea}^{+/-}$mice the cleavage of Talin-1 is also reduced.

The protease responsible for the cleavage, Calpain-2, is a large catalytic subunit which forms a heterodimer with a regulatory subunit, Calpain-4 (Calpain small subunit 1) [45]. In order to investigate the reduced cleavage of Talin1 , western blot for Calpain- 2 and -4 was performed and indicated similar expression levels of Calpain-2 and -4 in

Table 2 Differentially expressed peptides in platelets of $\mathrm{Nbea}^{+/-}$mice

\begin{tabular}{|c|c|c|c|c|c|c|c|c|c|}
\hline Identification & $\begin{array}{l}\text { Uniprot } \\
\text { ID }\end{array}$ & $\begin{array}{c}\mathrm{MW} \\
(\mathrm{kDa})\end{array}$ & $\begin{array}{l}\text { Identified } \\
\text { peptide }\end{array}$ & $\begin{array}{l}\text { Mono-isotopic } \\
\text { mass }\end{array}$ & Peptide sequence & Modification & Identification & $\begin{array}{c}\text { WT/HET } \\
\text { ratio }\end{array}$ & $P$ \\
\hline \multirow[t]{6}{*}{ Thymosin $\beta 4$} & \multirow[t]{6}{*}{ P20065 } & \multirow[t]{6}{*}{5.05} & \multirow[t]{2}{*}{ TYB4 } & \multirow[t]{2}{*}{4960.44} & SDKPDMAEIEKFDKSKLKKTE & \multirow[t]{2}{*}{ Acetylation } & \multirow{2}{*}{$\begin{array}{l}\text { MS/MS, clustering } \\
\text { [42] and [41] }\end{array}$} & \multirow[t]{2}{*}{5.2433} & \multirow[t]{2}{*}{0.048} \\
\hline & & & & & TQEKNPLPSKETIEEKQAGES & & & & \\
\hline & & & TYB4 & \multirow[t]{2}{*}{2150.07} & SDKPDMAEIEKFDKSKLK & \multirow[t]{4}{*}{ Acetylation } & \multirow{2}{*}{$\begin{array}{l}\text { Clustering [42] } \\
\text { and [41] }\end{array}$} & \multirow[t]{2}{*}{3.9551} & \multirow[t]{2}{*}{0.024} \\
\hline & & & $(1-18)$ & & & & & & \\
\hline & & & TYB4 & \multirow[t]{2}{*}{2828.36} & \multirow[t]{2}{*}{ KTETQEKNPLPSKETIEQEKQAGES } & & \multirow{2}{*}{$\begin{array}{l}\text { Clustering [42] } \\
\text { and [41] }\end{array}$} & \multirow[t]{2}{*}{4.4780} & \multirow[t]{2}{*}{0.036} \\
\hline & & & $(19-43)$ & & & & & & \\
\hline \multirow[t]{2}{*}{ Talin-1 } & \multirow[t]{2}{*}{ P26039 } & \multirow[t]{2}{*}{269.8} & TLN & \multirow[t]{2}{*}{1829.88} & \multirow[t]{2}{*}{ LPAIMRSGASGPENFQVG } & & \multirow{2}{*}{$\begin{array}{l}\text { Clustering [42] and } \\
\text { identified in } \\
\text { HEK MS/MS }\end{array}$} & \multirow[t]{2}{*}{2.4572} & \multirow[t]{2}{*}{0.032} \\
\hline & & & $(449-465)$ & & & & & & \\
\hline \multirow[t]{2}{*}{ Transgelin-2 } & \multirow[t]{2}{*}{ Q9WVA4 } & \multirow[t]{2}{*}{22.4} & TAGLN2 & \multirow[t]{2}{*}{2295.06} & \multirow[t]{2}{*}{ MGTNRGASQAGMTGYGMPRQIL } & & \multirow[t]{2}{*}{ MS/MS and [41] } & \multirow[t]{2}{*}{2.1505} & \multirow[t]{2}{*}{0.028} \\
\hline & & & $(178-199)$ & & & & & & \\
\hline \multirow[t]{2}{*}{ Thymosin $\beta 10$} & \multirow[t]{2}{*}{ Q6ZWY8 } & \multirow[t]{2}{*}{5.03} & TYB10 & 4933.43 & ADKPDMGEIASFDKAKLKKTE & Acetylation & MS/MS & 2.0944 & 0.020 \\
\hline & & & & & TQEKNTLPTKETIQEKRSEIS & & & & \\
\hline
\end{tabular}

The molecular weight (MW) is the MW of the precursor. A positive WT/HET ratio indicates a decrease in intensity in platelets of Nbea ${ }^{+/-}$mice. The length of the identified peptide is indicated between brackets with the numbers corresponding to the respective amino acids. Genotype differences were tested using the two-tailed $t$-test ( $\mathrm{n}=5$ mice/genotype). 


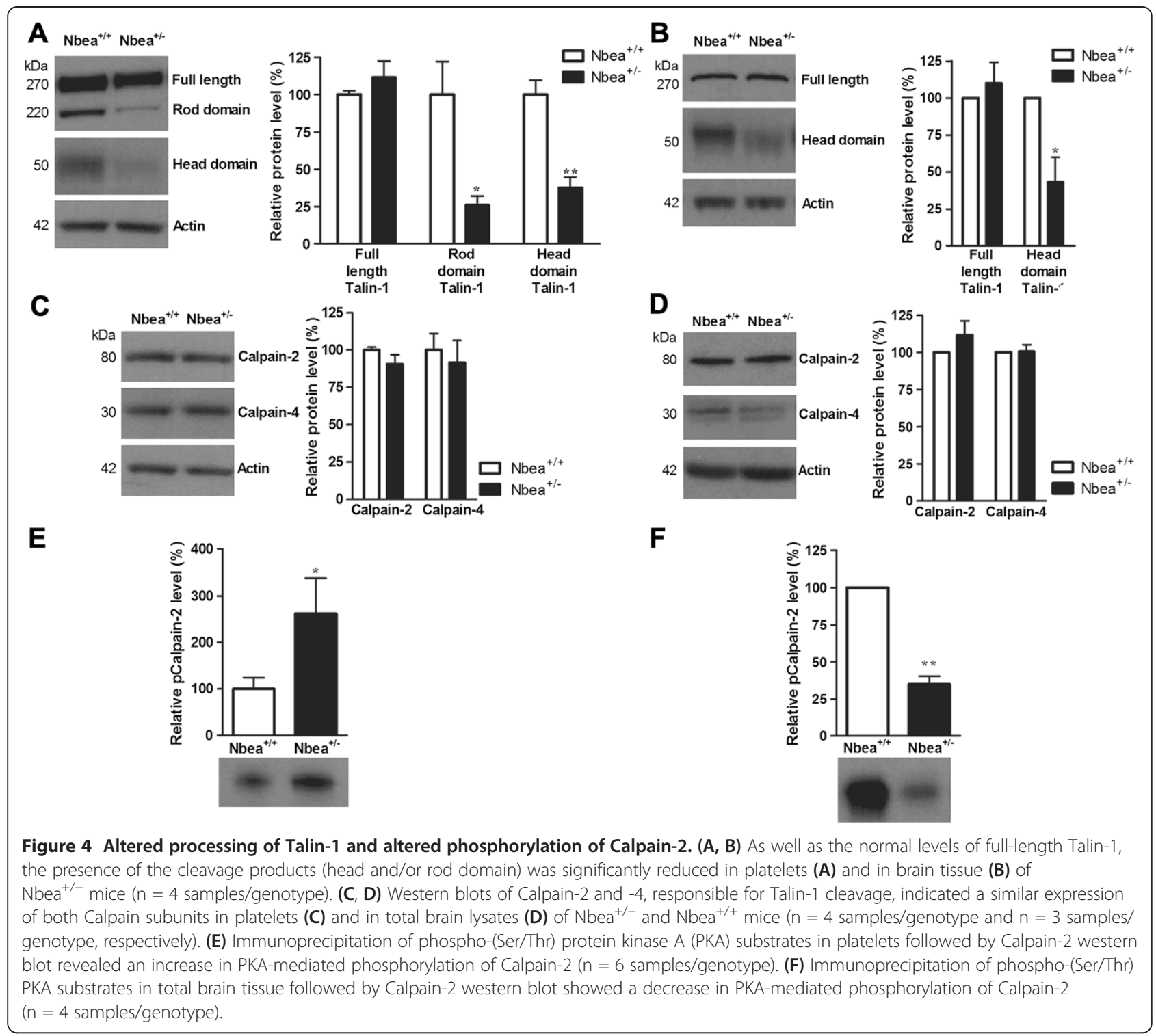

platelets $(\mathrm{n}=4$ samples/genotype; two-tailed $t$-test, $P=$ 0.31 and $P=0.67$, respectively) (Figure $4 C$ ) and in total brain lysates ( $\mathrm{n}=3$ samples/genotype; $t$-test for single means, $P=0.34$ and $P=0.92$, respectively) (Figure 4D) of wild-type and heterozygous Nbea mice.

The activity of Calpain-2 is negatively correlated with its phosphorylation status at a PKA consensus site $[46,47]$. As Nbea is an AKAP protein, Nbea haploinsufficiency might result in defects in the sequestering of inactive PKA and compartmentalization of PKA, leading to altered PKA activity in different subcellular locations [48]. Therefore, the phosphorylation status of Calpain-2 in resting platelets and brain was examined. The lack of an anti-phosphoCalpain-2 antibody specific for PKA phosphorylation was overcome by performing immunoprecipitation with a phospho-(Ser/ Thr) PKA substrate antibody detecting proteins containing a phosphorylated serine or threonine with an arginine at the -3 position, followed by western blot with Calpain-2 antibody. The level of phosphorylated Calpain-2 was significantly increased in platelets of $\mathrm{Nbea}^{+/-}$mice with an average ratio of 2.8 ( $\mathrm{n}=6$ samples/genotype; two-tailed $t$ test, $P=0.044$ ) (Figure $4 \mathrm{E})$. In contrast, the level of phosphorylated Calpain-2 in brain tissue of $\mathrm{Nbea}^{+/-}$mice was significantly decreased by a factor of $2.86(n=4$ samples/ genotype; $t$-test for single means, $P=0.001$ ) (Figure $4 \mathrm{~F}$ ).

To examine whether Nbea haploinsufficiency has a more general effect on PKA-dependent phosphorylation, western blot of platelet lysate with the phospho-(Ser/Thr) PKA substrate antibody was performed. Several phosphorylated proteins were detected in resting platelets of $\mathrm{Nbea}^{+/+}$and $\mathrm{Nbea}^{+/-}$mice and the phosphorylation of the three proteins with the highest molecular weight was significantly 
increased in $\mathrm{Nbea}^{+/-}$mice $(\mathrm{n}=4 \mathrm{samples} /$ genotype; $t$-test for single means, band $1, P=0.042$; band $2, P=0.027$; band $3, P=0.010$ ) (Figure $5 \mathrm{~A}$ ). Additionally, the phosphorylation of two other proteins was significantly reduced ( $t$-test for single means, band $7, P<0.001$ and band $8, P<0.001)$ whereas the phosphorylation of proteins 4 to 6 was unaltered $(t$-test for single means, $P=0.44, P=0.30$ and $P=0.62$, respectively) (Figure $5 \mathrm{~A}$ ). The same study was performed in brain tissue, which rendered several phosphorylated proteins. The phosphorylation of band 4, 6, 9 and 10 was significantly reduced in brain tissue of $\mathrm{Nbea}^{+/-}$mice ( $\mathrm{n}=5$ samples/genotype; $t$-test for single means, band $4, P=0.047$; band $6, P=0.003$; band $9, P=$ 0.009; band $10, P=0.024$ ) (Figure $5 \mathrm{~B}$ ).

\section{Discussion}

In this study we have confirmed a causal link between Nbea haploinsufficiency and abnormal granule morphology, similar to our previous observation in ASD patients [24]. Dense granules of $\mathrm{Nbea}^{+/-}$platelets were significantly smaller and showed a more pronounced shape change than $\mathrm{Nbea}^{+/+}$platelets. However, none of the 1,432 proteins identified in a proteomic screen was differentially expressed. Differential peptidomics of platelets did identify four actin-interacting peptides with a reduced presence in platelets of $\mathrm{Nbea}^{+/-}$mice. Validation of the peptidomic screen revealed reduced cleavage of Talin-1, most likely due to increased phosphorylation of Calpain-2 by PKA. The reduced cleavage of Talin-1 was confirmed in $\mathrm{Nbea}^{+/-}$

A
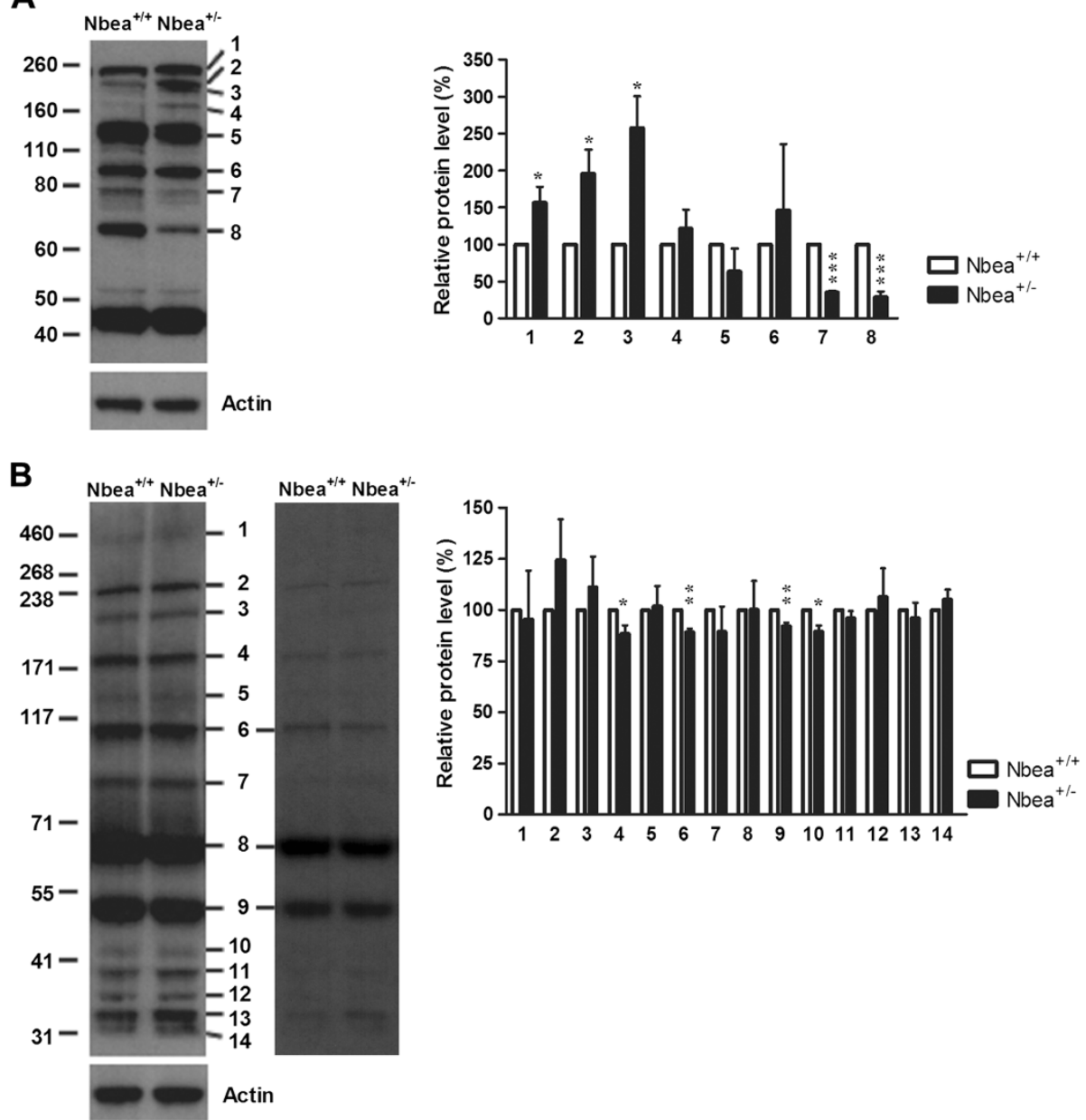

Figure 5 Abnormal Protein kinase A (PKA) phosphorylation pattern in $\mathbf{N b e a}^{+/-}$mice. Visualization of proteins phosphorylated by PKA revealed several changes in phosphorylation levels of proteins in resting platelets (A) and brain lysates (B) of Nbea ${ }^{+/-}$mice. Phosphorylation levels were first calculated within a litter, followed by $t$-test for single means, with the mean of wild-type samples being $100 \%$, to detect significant differences between $\mathrm{Nbea}^{+/+}$and $\mathrm{Nbea}^{+/-}$mice. (A) In resting platelets the three proteins with the highest molecular weight had a significantly higher phosphorylation status. The following three bands had an unaltered phosphorylation level whereas the last two bands had a significantly reduced phosphorylation profile ( $n=4$ samples/genotype). (B) Two different exposure times are shown for the PKA phosphorylation pattern of brain tissue, which were used for quantification. Image analysis revealed a significant decrease in phosphorylation level of four different proteins in brain tissue of $\mathrm{Nbea}^{+/-}$mice ( $n=5$ samples/genotype). 
total brain, but phosphorylation of Calpain-2 was decreased. The importance of Nbea as a regulator of PKA activity was further substantiated, as haploinsufficiency of Nbea positively and negatively affects PKA-mediated phosphorylation of a multitude of proteins in resting platelets and in brain.

Normal serotonin levels were detected in platelets and serum of $\mathrm{Nbea}^{+/-}$mice, which is consistent with the similar amount of dense granules per platelet in $\mathrm{Nbea}^{+/+}$and $\mathrm{Nbea}^{+/-}$mice as serotonin is taken up by platelets and stored in the dense granules [37]. Hyperserotonemia is one of the few biochemical anomalies reported in ASD patients and several possible causes have been suggested, such as increased synthesis or altered release of serotonin from enterochromaffin cells $[49,50]$. However, only $30 \%$ of ASD patients have been classified as being hyperserotonemic and increased levels of serotonin have also been detected in relatives of ASD patients [30,51]. These findings highlight the controversy regarding hyperserotonemia as a biomarker for ASD.

Several lines of evidence point to alterations in the cytoskeleton of platelets of $\mathrm{Nbea}^{+/-}$mice. First, an increased shape change upon collagen stimulation was observed for platelets of $\mathrm{Nbea}^{+/-}$mice. Interestingly, platelets from patients with a dense granule secretion defect also presented with a more pronounced shape change [31]. A similar shape change was noticed in platelets of patients with $\mathrm{Du}$ chenne muscular dystrophy, a disease characterized by a disturbed cytoskeletal organization [52]. Second, all peptides that have a significantly different level in platelets of $\mathrm{Nbea}^{+/-}$mice are actin-interacting peptides. Transgelin-2, also named SM $\beta 22$, was identified as an actin-associated protein with an unknown function [53]. Thymosin $\beta 4$ and $\beta 10$ are the main intracellular G-actin sequestering peptides present in most mammalian cells. Binding of Thymo$\sin \beta$ to G-actin prevents the polymerization to F-actin and reduced levels of Thymosin $\beta 4$ and $\beta 10$ lead to excessive formation of F-actin [54]. A decreased presence of Thymo$\sin \beta 4$ and $\beta 10$ in platelets of $\mathrm{Nbea}^{+/-}$mice might be indicative for a decreased expression in neurons as well. This could contribute to the excessive F-actin clusters detected in the soma, dendritic shafts and axons of hippocampal neuronal cultures of $\mathrm{Nbea}^{-/-}$mice and in the soma of cortical neurons of $\mathrm{Nbea}^{+/-}$mice, although the exact mechanism remains to be determined [22]. Of note, a proteomic study using platelets from patients with a dense granule secretion defect also revealed actin-binding proteins as the major change in differentially expressed proteins compared to control platelets [31].

Multiple F-actin binding sites have been identified in Talin-1, both in the head and rod domain $[55,56]$. The peptide of Talin-1 identified in the peptidomic screen is likely to be a degradation product of the rod domain. The diminished presence of this peptide in platelets of $\mathrm{Nbea}^{+/-}$ mice correlates with the reduced presence of the rod domain detected on western blot. Talin-1 is cleaved by Calpain-2 after amino acid 432, yielding the head and rod domain of Talin-1 [44]. Calpain-2 activity is regulated by phosphorylation of PKA; more specifically, phosphorylation of Ser369 or Thr370 results in decreased activity $[46,47]$. The observed increase in PKA-specific phosphorylation of Calpain-2 is therefore a likely cause of the reduced cleavage of Talin-1 in blood platelets.

It is known that the F3 subdomain in the head domain of Talin- 1 interacts with the cytoplasmic tail of $\beta$-integrin during the platelet activation process [57]. Therefore, alterations in platelet function might be expected based on the reduced presence of the head domain of Talin-1. However, in contrast to the conditional-knockout mouse models generated to study the molecular function of Talin-1, no complete ablation of Talin-1 was detected in platelets of $\mathrm{Nbea}^{+/-}$mice. Of note is the finding that heterozygous conditional Talin-1-knockout mouse models do not present alterations in platelet function [58].

In Wistar rats, Talin is detected at the membranes of granules and dense compartments in the megakaryocytes $[59,60]$. Wistar Furth rats, a rat model with abnormal thrombocytopoietic phenotype associated with morphologically aberrant megakaryocytes lack these dense compartments. It is hypothesized that the lack of cytoskeletal proteins such as Talin may be responsible for the absence of the dense compartments in megakaryocytes of Wistar Furth rats. Therefore, it is possible that the observed alterations in Talin-1 in $\mathrm{Nbea}^{+/-}$platelets contribute to the morphological differences of dense granules resulting in the reduced size of these dense granules.

Decreased cleavage of Talin-1 was also observed in total brain of $\mathrm{Nbea}^{+/-}$mice. However, PKA-mediated phosphorylation of Calpain-2 was decreased, leading to increased activity, in contrast to blood platelets. A possible explanation for this discrepancy between platelets and brain tissue is that platelets represent a pure cell population, whereas the brain is a mixed-cell population. Therefore, it is possible that cells with reduced phosphorylation of Calpain-2 are not the cells with high Talin-1 expression. For instance, the brain tissue consists of both excitatory and inhibitory neurons and earlier studies using neuronal cultures derived from either adult $\mathrm{Nbea}^{+/-}$mice or E18 $\mathrm{Nbea}^{-1-}$ mice revealed an imbalance in excitatory and inhibitory signaling with a more affected inhibitory neurotransmission [22,23,39]. Likewise, the phosphorylation status of Calpain-2 might be influenced by the excitatory/inhibitory imbalance present in the brain of $\mathrm{Nbea}^{+/-}$mice. In addition, the expression level of Nbea varies in different brain regions [16], which is likely to contribute to the alterations in PKA mediated phosphorylation on Calpain-2 upon Nbea haploinsufficiency. 
The altered level of PKA-phosphorylated Calpain-2 is in line with the reported increase in PKA-mediated phosphorylation of the cAMP response element-binding protein (CREB) in a neuroendocrine cell line after knockdown of Nbea, and indirectly, the increased level of brain-derived neurotrophic factor (BDNF), a target of phospho-CREB, in $\mathrm{Nbea}^{+/-}$mice [40]. As well as Calpain-2, the phosphorylation status of other proteins is affected in $\mathrm{Nbea}^{+/-}$ mice, as indicated by the increased or decreased intensity of several proteins detected in a western blot of lysates of resting platelets or brain tissue with antiphospho-(Ser/Thr) PKA substrate antibody. Although the alterations in PKA-mediated phosphorylation in total brain tissue from $\mathrm{Nbea}^{+/-}$mice are more subtle, this might also be the result of the mixed-cell population and variable Nbea expression levels. The concurrence of increased, unaltered and decreased PKA phosphorylation of different proteins caused by Nbea haploinsufficiency can be explained by the compartmentalizing role of AKAPs. Because of its AKAP domain, Nbea belongs to the AKAP family of proteins, which is known to scaffold PKA near its target proteins in a distinct subcellular compartment. Different AKAPs lead to different PKA compartmentalizations [48]. Haploinsufficiency of Nbea will lead to an altered subcellular distribution of PKA, which will cause a higher, lower or unchanged PKA-mediated phosphorylation of target proteins, depending on their subcellular presence. With a continuously expanding list of ASD candidate genes, there is increasing interest in signaling pathways linking ASD genetics with biological functions, such as growth and neurite outgrowth of developing neurons and synaptic function [61,62]. There is ample genetic evidence for the involvement of AKAPs in the etiology of ASD, and proteins encoded by 10 ASD-linked AKAP genes were shown to functionally integrate signaling cascades within and between several biological functions [63]. Haploinsufficiency of $N B E A$, one of the 10 ASD-linked AKAP genes, is thereby suggested to affect multiple pathways, most likely via the pleiotropic effect of altered PKA activity.

\section{Conclusions}

The characterization of platelets of $\mathrm{Nbea}^{+/-}$mice provides evidence for a causal relationship between NBEA haploinsufficiency in the patient and abnormal platelet morphology. Furthermore, the impaired cleavage of Talin-1, increased phosphorylation of Calpain-2, and an altered PKA-related phosphorylation fingerprint, emphasizes the importance of the AKAP domain of Nbea for its function. Spatiotemporal control of PKA activity appears to be an important physiological function of Nbea. These findings highlight that alterations in the phosphorylation status of proteins might contribute to the pathogenesis of ASD in at least a subgroup of patients.

\section{Additional file}

Additional file 1: Figure S1. The protein content of $\mathrm{Nbea}^{+/-}$mice contained 21 differentially expressed proteins compared to $\mathrm{Nbea}^{+/+}$mice, A representative gel of the protein profile of platelets of $\mathrm{Nbea}^{+/+}$and $\mathrm{Nbea}^{+/-}$mice after two dimensional-differential gel electrophoresis (2D-DiGE) is shown.

\section{Abbreviations}

2D-DiGE: Two dimensional-differential gel electrophoresis; AA: Amino acid; AKAP: A-kinase anchoring protein; ASD: Autism spectrum disorder; BEACH: Beige and Chediak-Higashi; CREB: CAMP response element-binding protein; Cy: Carbocyanine; DDT: Dithiothreitol; ELISA: Enzyme-linked immunosorbent assay; GAPDH: Glyceraldehyde-3-phosphate dehydrogenase; LC: Liquid chromatography; LDCV: Large dense-core vesicle; MPV: Mean platelet volume; MS: Mass spectrometry; MWU: Mann-Whitney U; PBS: Phosphate-buffered saline; PKA: Protein kinase A; PRP: Platelet rich plasma; Q-TOF: Quadrupole time-of-flight; SEM: Standard error of the mean; SNP: Single nucleotide polymorphism; SV: Synaptic vesicle.

\section{Competing interests}

The authors have no competing interests to declare.

\section{Authors' contributions}

KN and KT conducted experiments, analyzed and interpreted the data and drafted the manuscript. KB and EW conducted and analyzed experiments. MDM conducted experiments and assisted in the interpretation of the data. KF designed and conducted experiments, interpreted the data and helped to draft the manuscript. JC designed experiments, interpreted the data and helped to draft the manuscript. All authors read and approved the final manuscript.

\section{Acknowledgements}

We would like to thank Sandra Meulemans and Chantal Thys for the technical assistance, and the EM-facility of the Center of Human Genetics, VIB KU Leuven for the use of their appliances. This work was supported by the agentschap voor Innovatie door Wetenschap en Technologie Vlaanderen (IWTVlaanderen), the Fund for Scientific Research (FWO-Vlaanderen) (grants G.0490.10 N and G.0743.09) steunfonds Marguerite-Marie Delacroix, KU Leuven (IDO/08/013; GOA/2009/13; GOA/12/24), and a grant of the Interuniversity Attraction Poles Programme (P7/13) - Belgian Federal Science Policy). The funding sources were not involved in the design, collection, analysis or interpretation of the data; in writing the manuscript; or in the decision to submit the manuscript for publication.

\section{Author details}

'Department of Human Genetics, Laboratory for Biochemical Neuroendocrinology, KU Leuven, 3000 Leuven, Belgium. ${ }^{2}$ Leuven Autism Research Consortium (LAuRes), KU Leuven, 3000 Leuven, Belgium.

${ }^{3}$ Department of Cardiovascular Sciences, Center for Molecular and Vascular Biology, KU Leuven, 3000 Leuven, Belgium. ${ }^{4}$ Department of Cellular and Molecular Medicine, Laboratory of Protein Phosphorylation and Proteomics, KU Leuven, 3000 Leuven, Belgium.

Received: 18 February 2013 Accepted: 8 October 2013 Published: 4 November 2013

\section{References}

1. Betancur C: Etiological heterogeneity in autism spectrum disorders: more than 100 genetic and genomic disorders and still counting. Brain Res 2011, 1380:42-77.

2. Abrahams B, Geschwind D: Advances in autism genetics: on the threshold of a new neurobiology. Nat Rev Genet 2008, 9:341-355

3. Castermans D, Wilquet V, Parthoens E, Huysmans C, Steyaert J, Swinnen L, Fryns JP, Van de Ven W, Devriendt $K$ : The neurobeachin gene is disrupted by a translocation in a patient with idiopathic autism. J Med Genet 2003, 40:352-356.

4. Reddy K: Cytogenetic abnormalities and fragile- $X$ syndrome in autism spectrum disorder. BMC Med Genet 2005, 6:3.

5. Ritvo E, Mason-Brothers A, Menkes J, Sparkes R: Association of autism, retinoblastoma, and reduced esterase D activity. Arch Gen Psychiatry 1988, 45:600. 
6. Smith M, Woodroffe A, Smith R, Holguin S, Martinez J, Filipek P, Modahl C, Moore B, Bocian M, Mays L, Laulhere T, Flodman P, Spence MA: Molecular genetic delineation of a deletion of chromosome $13 q 12->$ q13 in a patient with autism and auditory processing deficits. Cytogenet Genome Res 2002, 98:233-239.

7. Kaminsky EB, Kaul V, Paschall J, Church DM, Bunke B, Kunig D, Moreno-DeLuca D, Moreno-De-Luca A, Mulle JG, Warren ST, Richard G, Compton JG, Fuller AE, Gliem TJ, Huang S, Collinson MN, Beal SJ, Ackley T, Pickering DL, Golden DM, Aston E, Whitby H, Shetty S, Rossi MR, Rudd MK, South ST, Brothman AR, Sanger WG, lyer RK, Crolla JA, et al: An evidence-based approach to establish the functional and clinical significance of copy number variants in intellectual and developmental disabilities. Genet Med 2011, 13:777-784.

8. Celestino-Soper PB, Shaw CA, Sanders SJ, Li J, Murtha MT, Ercan-Sencicek AG, Davis L, Thomson S, Gambin T, Chinault AC, Ou Z, German JR, Milosavljevic A, Sutcliffe JS, Cook EH Jr, Stankiewicz P, State MW, Beaudet AL: Use of array $\mathrm{CGH}$ to detect exonic copy number variants throughout the genome in autism families detects a novel deletion in TMLHE. Hum Mol Genet 2011, 20:4360-4370.

9. Sanders SJ, Ercan-Sencicek AG, Hus V, Luo R, Murtha MT, Moreno-De-Luca D, Chu SH, Moreau MP, Gupta AR, Thomson SA, Mason CE, Bilguvar K, Celestino-Soper PB, Choi M, Crawford EL, Davis L, Wright NR, Dhodapkar RM, DiCola M, DiLullo NM, Fernandez TV, Fielding-Singh V, Fishman DO, Frahm S, Garagaloyan R, Goh GS, Kammela S, Klei L, Lowe JK, Lund SC, et al: Multiple recurrent de novo CNVs, including duplications of the $7 q 11.23$ Williams syndrome region, are strongly associated with autism. Neuron 2011, 70:863-885.

10. Prasad A, Merico D, Thiruvahindrapuram B, Wei J, Lionel AC, Sato D, Rickaby J, Lu C, Szatmari P, Roberts W, Fernandez BA, Marshall CR, Hatchwell E, Eis PS, Schrerer SW: A discovery resource of rare copy number variations in individuals with autism spectrum disorder. G3 (Bethesda) 2012, 2:1665-1685.

11. Anney R, Klei L, Pinto D, Regan R, Conroy J, Magalhaes TR, Correia C, Abrahams BS, Sykes N, Pagnamenta AT, Almeida J, Baccheli E, Bailey AJ, Baird G, Battaglia A, Berney T, Bolshakova N, Bölte S, Bolton PF, Bourgeron T, Brennan S, Brian J, Carson AR, Casallo G, Casey J, Chu SH, Cochrane L, Corsello C, Crawford EL, Crossett A, et al: A genome-wide scan for common alleles affecting risk for autism. Hum Mol Genet 2010, 19:4072-4082.

12. Barrett $S$, Beck J, Bernier R, Bisson E, Braun T, Casavant T, Childress D, Folstein S, Garcia M, Gardiner M, Gilman S, Haines JL, Hopkins K, Landa R, Meyer NH, Mullane JA, Nishimura DY, Palmer P, Piven J, Purdy J, Santangelo SL, Searby C, Sheffield V, Singleton J, Slager S, Struchen T, Svenson S, Vieland V, Wang K, Winklosky B: An autosomal genomic screen for autism. Collaborative linkage study of autism. Am J Med Genet 1999, 88:609-615.

13. Bradford $Y$, Haines J, Hutcheson $H$, Gardiner M, Braun T, Sheffield V, Cassavant T, Huang W, Wang K, Vieland V, Folstein S, Santangelo S, Piven J: Incorporating language phenotypes strengthens evidence of linkage to autism. Am J Med Genet 2001, 105:539-547.

14. Savelyeva L, Sagulenko E, Schmitt J, Schwab M: The neurobeachin gene spans the common fragile site FRA13A. Hum Genet 2006, 118:551-558.

15. Volders $K$, Nuytens $K$, Creemers JW: The autism candidate gene neurobeachin encodes a scaffolding protein implicated in membrane trafficking and signaling. Curr Mol Med 2011, 11:204-217.

16. Wang X, Herberg FW, Laue MM, Wullner C, Hu B, Petrasch-Parwez E, Kilimann MW: Neurobeachin: a protein kinase A-anchoring, beige/chediakhigashi protein homolog implicated in neuronal membrane traffic. J Neurosci 2000, 20:8551-8565.

17. Breidenbach $M$, Brunger $A$ : New insights into clostridial neurotoxin-SNARE interactions. Trends Mol Med 2005, 11:377-381.

18. Burgess A, Mornon JP, de Saint-Basile G, Callebaut I: A concanavalin A-like lectin domain in the CHS1/LYST protein, shared by members of the BEACH family. Bioinformatics 2009, 25:1219-1222.

19. Gebauer D, Li J, Jogl G, Shen Y, Myszka D, Tong L: Crystal structure of the PHBEACH domains of human LRBA/BGL. Biochemistry 2004, 43:14873-14880.

20. Wang N, Wu WI, De Lozanne A: BEACH family of proteins: phylogenetic and functional analysis of six dictyostelium BEACH proteins. J Cell Biochem 2002, 86:561-570.

21. Su Y, Balice-Gordon RJ, Hess DM, Landsman DS, Minarcik J, Golden J, Hurwitz I, Liebhaber SA, Cooke NE: Neurobeachin is essential for neuromuscular synaptic transmission. J Neurosci 2004, 24:3627-3636.
22. Niesmann K, Breuer D, Brockhaus J, Born G, Wolff I, Reissner C, Kilimann MW Rohlmann A, Missler M: Dendritic spine formation and synaptic function require neurobeachin. Nat Commun 2011, 2:557.

23. Nair R, Lauks J, Jung S, Cooke NE, de Wit H, Brose N, Kilimann MW, Verhage $M$, Rhee J: Neurobeachin regulates neurotransmitter receptor trafficking to synapses. J Cell Biol 2013, 200:61-80.

24. Castermans D, Volders K, Crepel A, Backx L, De Vos R, Freson K, Meulemans S, Vermeesch JR, Schrander-Stumpel CT, De Rijk P, Del-Favero J, Van Geet C: SCAMP5, NBEA and AMISYN: three candidate genes for autism involved in secretion of large dense-core vesicles. Hum Mol Genet 2010, 19:1368-1378

25. Reed GL, Fitzgerald ML, Polgar J: Molecular mechanisms of platelet exocytosis: insights into the "secrete" life of thrombocytes. Blood 2000, 96:3334-3342.

26. Goubau C, Buyse GM, Di Michele M, Van Geet C, Freson K: Regulated granule trafficking in platelets and neurons: a common molecular machinery. Eur J Paediatr Neurol 2012, 17(2):117-125.

27. Pletscher A: Blood platelets as neuronal models: use and limitations. Clin Neuropharmacol 1986, 9(Suppl 4):344-346.

28. Albers CA, Cvejic A, Favier R, Bouwmans EE, Alessi MC, Bertone P, Jordan G, Kettleborough RN, Kiddle G, Kostadima M, Read RJ, Sipos B, Sivapalaratnam S, Smethurst PA, Stephens J, Voss K, Nurden A, Rendon A, Nurden P, Ouwehand WH: Exome sequencing identifies NBEAL2 as the causative gene for gray platelet syndrome. Nat Genet 2011, 43:735-737.

29. Introne W, Boissy RE, Gahl WA: Clinical, molecular, and cell biological aspects of chediak-higashi syndrome. Mol Genet Metab 1999, 68:283-303.

30. Hranilovic D, Bujas-Petkovic Z, Tomicic M, Bordukalo-Niksic T, Blazevic S, Cicin-Sain L: Hyperserotonemia in autism: activity of 5HT-associated platelet proteins. J Neural Transm 2009, 116:493-501.

31. Di Michele M, Thys C, Waelkens E, Overbergh L, D'Hertog W, Mathieu C, De Vos R, Peerlinck K, Van Geet C, Freson K: An integrated proteomics and genomics analysis to unravel a heterogeneous platelet secretion defect. J Proteomics 2011, 74:902-913.

32. Freson $K$, Hashimoto $H$, Thys C, Wittevrongel C, Danloy S, Morita Y, Shintani N, Tomiyama Y, Vermylen J, Hoylaerts MF, Baba A, Van Geet C: The pituitary adenylate cyclase-activating polypeptide is a physiological inhibitor of platelet activation. J Clin Invest 2004, 113:905-912.

33. Freson K, De Vos R, Wittevrongel C, Thys C, Defoor J, Vanhees L, Vermylen J, Peerlinck K, Van Geet C: The TUBB1 Q43P functional polymorphism reduces the risk of cardiovascular disease in men by modulating platelet function and structure. Blood 2005, 106:2356-2362.

34. Pujol-Moix N, Hernandez A, Escolar G, Espanol I, Martinez-Brotons F, Mateo $\mathrm{J}$ : Platelet ultrastructural morphometry for diagnosis of partial deltastorage pool disease in patients with mild platelet dysfunction and/or thrombocytopenia of unknown origin. A study of 24 cases. Haematologica 2000, 85:619-626.

35. Weiss HJ, Lages B, Vicic W, Tsung LY, White JG: Heterogeneous abnormalities of platelet dense granule ultrastructure in 20 patients with congenital storage pool deficiency. Br J Haematol 1993, 83:282-295.

36. Boonen K, Husson SJ, Landuyt B, Baggerman G, Hayakawa E, Luyten WH, Schoofs $L$ : Identification and relative quantification of neuropeptides from the endocrine tissues. Methods Mol Biol 2010, 615:191-206.

37. Mercado CP, Kilic F: Molecular mechanisms of SERT in platelets: regulation of plasma serotonin levels. Mol Interv 2010, 10:231-241.

38. Stalker TJ, Newman DK, Ma P, Wannemacher KM, Brass LF: Platelet signaling. Handb Exp Pharmacol 2012, 210:59-85.

39. Medrihan L, Rohlmann A, Fairless R, Andrae J, Doring M, Missler M, Zhang W, Kilimann MW: Neurobeachin, a protein implicated in membrane protein traffic and autism, is required for the formation and functioning of central synapses. J Physio/ 2009, 587:5095-5106.

40. Nuytens K, Gantois I, Stijnen P, Iscru E, Laeremans A, Serneels L, Van Eylen L, Liebhaber SA, Devriendt K, Balschun D, Arckens L, Creemers JW, D'Hooge R: Haploinsufficiency of the autism candidate gene neurobeachin induces autism-like behaviors and affects cellular and molecular processes of synaptic plasticity in mice. Neurobiol Dis 2013, 51:144-151.

41. Tammen H, Schulte I, Hess R, Menzel C, Kellmann M, Mohring T, SchulzKnappe P: Peptidomic analysis of human blood specimens: comparison between plasma specimens and serum by differential peptide display. Proteomics 2005, 5:3414-3422.

42. Menschaert G, Vandekerckhove TT, Landuyt B, Hayakawa E, Schoofs L, Luyten W, Van Criekinge W: Spectral clustering in peptidomics studies 
helps to unravel modification profile of biologically active peptides and enhances peptide identification rate. Proteomics 2009, 9:4381-4388.

43. Bate N, Gingras AR, Bachir A, Horwitz R, Ye F, Patel B, Goult BT, Critchley DR: Talin contains a C-terminal calpain2 cleavage site important in focal adhesion dynamics. PLoS One 2012, 7:e34461.

44. Franco SJ, Rodgers MA, Perrin BJ, Han J, Bennin DA, Critchley DR, Huttenlocher A: Calpain-mediated proteolysis of talin regulates adhesion dynamics. Nat Cell Biol 2004, 6:977-983.

45. Ono Y, Sorimachi H: Calpains: an elaborate proteolytic system. Biochim Biophys Acta 2012, 1824:224-236.

46. Shiraha H, Glading A, Chou J, Jia Z, Wells A: Activation of m-calpain (calpain II) by epidermal growth factor is limited by protein kinase A phosphorylation of m-calpain. Mol Cell Biol 2002, 22:2716-2727.

47. Smith SD, Jia Z, Huynh KK, Wells A, Elce JS: Glutamate substitutions at a PKA consensus site are consistent with inactivation of calpain by phosphorylation. FEBS Lett 2003, 542:115-118.

48. Corstens GJ, van Boxtel R, van den Hurk MJ, Roubos EW, Jenks BG: The effects of disruption of a kinase anchoring protein-protein kinase A association on protein kinase A signalling in neuroendocrine melanotroph cells of Xenopus laevis. J Neuroendocrinol 2006, 18:477-483.

49. Croonenberghs J, Verkerk R, Scharpe S, Deboutte D, Maes M: Serotonergic disturbances in autistic disorder: L-5-hydroxytryptophan administration to autistic youngsters increases the blood concentrations of serotonin in patients but not in controls. Life Sci 2005, 76:2171-2183.

50. Janusonis S: Statistical distribution of blood serotonin as a predictor of early autistic brain abnormalities. Theor Biol Med Model 2005, 2:27.

51. Cook EH Jr, Arora RC, Anderson GM, Berry-Kravis EM, Yan SY, Yeoh HC, Sklena PJ, Charak DA, Leventhal BL: Platelet serotonin studies in hyperserotonemic relatives of children with autistic disorder. Life Sci 1993, 52:2005-2015.

52. Labarque V, Freson $K$, Thys C, Wittevrongel C, Hoylaerts MF, De Vos R, Goemans N, Van Geet C: Increased Gs signalling in platelets and impaired collagen activation, due to a defect in the dystrophin gene, result in increased blood loss during spinal surgery. Hum Mol Genet 2008, 17:357-366.

53. Zhang JC, Helmke BP, Shum A, Du K, Yu WW, Lu MM, Davies PF, Parmacek MS: SM22beta Encodes a lineage-restricted cytoskeletal protein with a unique developmentally regulated pattern of expression. Mech Dev 2002, 115:161-166.

54. Yu FX, Lin SC, Morrison-Bogorad M, Atkinson MA, Yin HL: Thymosin beta 10 and thymosin beta 4 are both actin monomer sequestering proteins. J Biol Chem 1993, 268:502-509.

55. Smith SJ, McCann RO: A C-terminal dimerization motif is required for focal adhesion targeting of Talin 1 and the interaction of the Talin 1 I/LWEQ module with F-actin. Biochemistry 2007, 46:10886-10898.

56. Lee HS, Bellin RM, Walker DL, Patel B, Powers P, Liu H, Garcia-Alvarez B, de Pereda JM, Liddington RC, Volkmann N, Hanein D, Critchley DR, Robson RM: Characterization of an actin-binding site within the talin FERM domain. J Mol Biol 2004, 343:771-784.

57. Tadokoro S, Shattil SJ, Eto K, Tai V, Liddington RC, de Pereda JM, Ginsberg $\mathrm{MH}$, Calderwood DA: Talin binding to integrin beta tails: a final common step in integrin activation. Science 2003, 302:103-106.

58. Nieswandt B, Moser M, Pleines I, Varga-Szabo D, Monkley S, Critchley D, Fassler R: Loss of talin 1 in platelets abrogates integrin activation, platelet aggregation, and thrombus formation in vitro and in vivo. $J$ Exp Med 2007, 204:3113-3118.

59. Jackson CW, Hutson NK, Steward SA, Stenberg PE: A unique talin antigenic determinant and anomalous megakaryocyte talin distribution associated with abnormal platelet formation in the wistar furth rat. Blood 1992, 79:1729-1737.

60. Stenberg PE, Beckstead JH, Jackson CW: Wistar furth rat megakaryocytes lack dense compartments and intercellular plaques, membranous structures rich in cytoskeletal proteins. Cell Adhes Commun 1998, 5:397-407.

61. Hussman JP, Chung RH, Griswold AJ, Jaworski JM, Salyakina D, Ma D, Konidari I, Whitehead PL, Vance JM, Martin ER, Cuccaro ML, Gilbert JR, Haines JL, Pericak-Vance MA: A noise-reduction GWAS analysis implicates altered regulation of neurite outgrowth and guidance in autism. Mol Autism 2011, 2:1.
62. Gilman SR, lossifov I, Levy D, Ronemus M, Wigler M, Vitkup D: Rare de novo variants associated with autism implicate a large functional network of genes involved in formation and function of synapses. Neuron 2011, 70:898-907.

63. Poelmans G, Franke B, Pauls DL, Glennon JC, Buitelaar JK: AKAPs integrate genetic findings for autism spectrum disorders. Transl Psychiatry 2013, 3:e270.

doi:10.1186/2040-2392-4-43

Cite this article as: Nuytens et al:: Platelets of mice heterozygous for neurobeachin, a candidate gene for autism spectrum disorder, display protein changes related to aberrant protein kinase A activity. Molecular Autism 2013 4:43.

\section{Submit your next manuscript to BioMed Central and take full advantage of:}

- Convenient online submission

- Thorough peer review

- No space constraints or color figure charges

- Immediate publication on acceptance

- Inclusion in PubMed, CAS, Scopus and Google Scholar

- Research which is freely available for redistribution 